\title{
LEGITIMASI KEKUASAAN DAN HUBUNGAN PENGUASA-RAKYAT DALAM PEMIKIRAN POLITIK SUKU DAYAK MA'ANYAN
}

\author{
Kisno Hadi \\ Program Studi Ilmu Pemerintahan \\ Fakultas Ilmu Sosial dan Ilmu Politik Universitas Kristen Palangka Raya \\ Email:kisnohadi@yahoo.co.id
}

\begin{abstract}
This article is a result of research on power legitimation and relation of rulers and people in political thought of Dayak Ma'anyan context. This Political thought was practiced by Nan Sarunai at the past centuries and inherited by some of people but the rest is disappeared. By the time of decentralization and the beginning of democration era at 1998, some of the concept was adopted like as on legitimating of power and relation between ruler and people in power. The implementation of the concept is seen in many ways e.g. in development of East Barito Regency which is believed as a continuation of Nan Sarunai Kingdom, the bestowal of past adat leader titles for regents or governors (dudus) and this ceremonial creating dependency relation between ruler and people which is people as the object. The aims of this research are to find out the thought and practice of power legitimation in the past and the implementation of power legitimation at present. Research use explanatory descriptive method and the data will analyze by interpretative descriptive. Research was held from April, 2014 to March, 2017 in community Dayak Ma'anyan in East Barito Regency, especially in Paju Epat District i.e Balawa, Murutuwu, Siong, and Telang. These villages believed still pratice and preserve adat of Nan Sarunai completely. Writer conduct deep interview with local adat leader i.e. Mantir, Damang, Pangulu Adat, and Pamakal. Use oral data likes Taliwakas (stories on leader), Hiyang Wadian (sacred song of priest which is sing in adat ritual), Sorosilah (histories of leader), and customary law of Dayak Ma'anyan. Data interpretation use Legitimacy Theory or religious legitimating of Franz Magnis Susesno and theory of relation between rulers - people from Soemarsaid Moertono.
\end{abstract}

Keywords: Dayak Ma'anyan Tribe; Leader and People; Legitimacy; Political Thought; Power.

\begin{abstract}
ABSTRAK
Tulisan ini merupakan hasil penelitian mengenai keabsahan atau legitimasi kekuasaan dan hubungan penguasa dengan rakyat dalam konteks pemikiran politik suku Dayak Ma'anyan. Pemikiran politik ini pernah dipraktikkan di masa lalu dalam kehidupan masyarakat suku pada masa kerajaan Nan Sarunai dan sesudahnya, dan kini mereka warisi. Sebagian pemikiran itu sudah tidak dipraktikkan lagi dan hanya melekat dalam sejarah pemikiran saja. Akan tetapi, desentraliasi dan demokrasi sejak kejatuhan Soeharto tahun 1998, memberi peluang bagi mereka mempraktikkan kembali beberapa konsep pemikiran itu yaitu seperti keabsahan atau legitimasi kekuasaan serta konsep hubungan penguasa dengan rakyat dalam kekuasaan. Implementasinya adalah melalui pembangunan Kabupaten Barito Timur disebut sebagai kelanjutan Nan Sarunai, pemberian gelar pemimpin adat kepada kepala daerah dengan mengambil gelar dari pemimpin masa lalu, dan hubungan penguasa dengan rakyat yang diciptakan saling ketergantungan antara penguasa dengan rakyat di mana rakyat ditempatkan sebagai sasaran dan tujuan pelaksanaan kekuasaan melalui konsep pelantikan pemimpin secara adat (dudus)
\end{abstract}


terhadap kepala daerah. Untuk itu penelitian ini dilakukan untuk mengetahui implementasi konsep tersebut di masa kini dan bagaimana pemikiran dan praktiknya di masa lalu. Metode penelitian menggunakan metode deskriptif explanatory dengan analisis data deskriptif interpretatif. Penelitian dilakukan sejak bulan April 2014 sampai Maret 2017 di daerah suku Dayak Ma'anyan di Kabupaten Barito Timur, terutama kecamatan Paju Epat khususnya desa Balawa, Murutuwu, Siong, dan Telang yang masih mewarisi adat istiadat dari Nan Sarunai. Penulis melakukan wawancara mendalam dengan tokoh adat setempat seperti Mantir, Damang, Pangulu Adat, dan Pamakal. Penulis menggunakan data lisan seperti Taliwakas (cerita tentang pemimpin), Hiyang Wadian (nyanyian suci imam suku dalam upacara adat), Sorosilah (sejarah asal usul pemimpin), dan hukum adat Dayak Ma'anyan. Interpretasi data menggunakan teori keabsahan atau legitimasi religius Franz Magnis Suseno dan teori hubungan penguasa-rakyat dari Soemarsaid Moertono.

Kata Kunci: Keabsahan; Kekuasaan; Pemikiran Politik; Pemimpin dan Rakyat; Suku Dayak Ma'anyan.

\section{PENGANTAR}

Politik lokal pasca-kejatuhan pemerintahan Soeharto tahun 1998 adalah era politik identitas, baik agama maupun etnis. Era ini adalah era penegasan identitas yang mengejutkan sekaligus dilematis. Mengejutkan karena era desentralisasi politik dan pemerintahan, yang dikonsepkan untuk efisiensi administrasi pemerintahan modern sekaligus menghadirkan demokrasi di tingkat lokal, sedangkan kebangkitan komunitarian tidak pernah diperhitungkan, tetapi malah menjadi bagian penting desentralisasi. Dilematis karena persoalan kebangkitan identitas berarti kebangkitan simbol-simbol kekuasaan sebelum republik ini berdiri yang merepresentasikan feodalisme (Klinken, 2010: 166).

Kebangkitan identitas juga terjadi di kalangan suku Dayak Ma'anyan di Kalimantan Tengah. Masyarakat suku Dayak Ma'anyan yang mayoritas bertempat tinggal di Kabupaten Barito Timur memiliki sejarah yang unik dan panjang dalam mendeskripsikan identitas mereka. Mereka memiliki kronik tentang kerajaan Nan Sarunai pada abad 13 dan 14 yang hancur karena diserang Jawa (Majapahit) dalam sebuah peristiwa yang mereka kenang sebagai "Sarunai Usak Jawa" (Sarunai dihancurkan Jawa) (Bae, dkk, 1995: 52, 375). Mereka mengenang Nan Sarunai sebagai negeri yang berdaulat secara ekonomi, politik dan sosial budaya, pusat pelaksanaan pemerintahan, menetapkan pemimpin, ada kepemimpinan Mantir Epat Pangulu Isa sebagai pelaksana adat, dan pemerintahan serta Miharaja sebagai pemimpin pemerintahan. Sampai kini Nan Sarunai dikenang sebagai negeri tempat masyarakat suku Dayak Ma'anyan mengenyam masa keemasan dan kejayaan (Wawancara, Bhaterius, 2017). Kehidupan mereka di masa kini diselimuti kehidupan suku yang kental terutama dalam menjatuhkan pilihan politik saat pemilihan kepala daerah, dan selalu dikaitkan dengan sejarah politik masa lalu itu.

Reformasi 1998 memberi ruang bagi mereka memperjuangkan kembali identitas etnis dan politik dari masa lalu itu. Kabupaten Barito Timur yang diperjuangkan pembentukannya sejak tahun 1964, akhirnya terbentuk tahun 2002, dan diklaim sebagai rentetan atau kelanjutan kerajaan Nan Sarunai yang disebut daerah Tanah Datar (Pilakoanu, 2010; Usop, 1978: 40-42; Wawancara, Usop, 2014). Sebab itu, pada awal pembentukannya, muncul perdebatan di kalangan tokoh, ada yang ingin menamainya Tanah Datar dan sebagian lagi hendak memberi nama Barito Timur (Alkim, 2004: 6-7; Wawancara, Ngepek, 2014; Wawancara, Dandan, 2017), yang akhirnya disepakati nama Barito Timur.

Dalam konteks adat oleh kalangan tokoh adat Kabupaten Barito Timur disebut sebagai "Nan Sarunai Wau" (Nan Sarunai Baru), atau "Nan Sarunai Mulek Kala Mula" (Nan Sarunai kembali seperti dulu). Peran pemimpin tradisional sebagai warisan Nan Sarunai yaitu Mantir Epat Pangulu Isa masih dipraktikkan di desa-desa. Mereka juga mempertahankan kekuasaan kepala adat yang disebut Damang Kepala Adat yang memerintah secara adat meliputi beberapa kecamatan. Di seluruh Kalteng, hanya di Kabupaten Barito Timur Damang Kepala Adat menjadi pemimpin 
adat berbasiskan wilayah suku atau etnis, bukan kecamatan seperti di daerah lain. Suku dipimpin oleh Damang Kepala Adat di maksud adalah Ma'anyan Paju Epat, Ma'anyan Kampung Sapuluh, Ma'anyan Banu Lima, dan Ma'anyan Paku Karau. Terdapat 4 (empat) orang Damang Kepala Adat yang memerintah secara adat untuk 10 wilayah kecamatan.

Mereka memistifikasi kepala daerah seperti Bupati dengan memberi gelar pemimpin suku, harapannya tokoh tersebut dapat dimitoskan dan membawa kebaikan bagi mereka di masa kini. Dua orang Bupati Barito Timur yaitu Zain Alkim (periode 2003-2013) dan Ampera A. Y. Mebas (periode 2013-2018) serta Teras Narang Gubernur Kalteng dua periode (2005-2015) diberi gelar pemimpin suku Dambung Panning Maleh. Dalam pandangan kalangan tokoh adat, legitimasi atau keabsahan pemimpin secara tradisional penting dilekatkan kepada pribadi pemimpin atau penguasa kendati pemimpin tersebut memegang kendali dalam politik modern. Legitimasi atau keabsahan mengacu kepada peraturan yang ditetapkan oleh adat. Adat yang termanifestasi dalam hukum adat mengesahkan pemimpin atau penguasa berasal dari golongan tutur amau (kelas pemimpin), sebab ia memimpin orang banyak, dan tugas utama pemimpin atau penguasa adalah membuat tenteram kehidupan rakyat (Wawancara, Udir, 2017). Oleh karena itu, pemimpin politik diberi gelar pemimpin suku untuk memberi "pangiwuruh" (kharisma) sehingga ia berpengaruh dan mampu menjalankan tugasnya sebagai kepala daerah (Wawancara Suban, Udir, 2017). Sementara pola hubungan penguasa dengan rakyat termuat dalam konsep tutur amaututur ime yang tergambarkan dalam konsep hukum adat Dayak Ma'anyan, yang sejajar dengan konsep kawula-gusti di Jawa. Konsep ini tidak hanya menggambarkan antara pihak penguasa dengan pihak yang dikuasai, tetapi memperlihatkan saling ketergantungan juga.

Suku Dayak Ma'anyan adalah kelompok masyarakat suku yang memiliki ikatan kultural sangat kuat dan mempengaruhi tingkah laku sehari-hari termasuk tingkah laku politik. Ikatan kultural mengharuskan mereka me- nentukan pemimpin politik sekaligus pemimpin kultural, guna menjadi pemersatu masyarakat suku, dan merepresentasi kepentingan mereka secara lebih luas. Sosok pemimpin politik yang diangkat menjadi patron adalah pemimpin yang dapat mempersatukan dan merepresentasi seluruh kepentingan mereka baik secara ekonomi maupun politik. Sama tatkala tahun 1930an sampai 1950an representasi kepentingan mereka disalurkan melalui berbagai organisasi adat seperti Pakat Dayak (PD), Partai Persatuan Dayak (PPD), dan Gerakan Mandau Talawang Pancasila (GMTPS). Di tahun 1950an bersama kelompok suku Dayak lainnya mereka merasa berada di bawah bayang-bayang kekuasaan orang Banjar (Melayu) sehingga menuntut pembentukan Provinsi Kalteng untuk orang Dayak. Di masa kini, representasi kepentingan mereka dipercayakan melalui peran elite lokal seperti bupati dan gubernur yang diangkat menjadi patron sebagai pemersatu serta melalui lembaga yang berbasiskan adat seperti Dewan Adat Dayak (DAD) dan Dusmala.

Untuk itu, tulisan yang merupakan hasil penelitian ini hendak menjawab pertanyaan “bagaimana legitimasi kekuasaan dan hubungan penguasa dengan rakyat dalam pemikiran politik suku Dayak Ma'anyan?" Tulisan ini mendeskripsikan pemikiran politik suku Dayak Ma'anyan mengenai kekuasaan, khususnya mengenai keabsahan atau legitimasi kekuasaan dan hubungan penguasa-rakyat.

Studi lain terkait legitimasi kekuasaan tradisional bersifat adikodrati yang relevan dengan penelitian tentang masyarakat suku Dayak Ma'anyan adalah studi tentang masyarakat Bugis-Makassar (Mattulada, 1985: 387), Tana Toraja (Pasande, 2011: 217-218), dan Bali (Waren, 2010: 187-188; Nordholt, 2007: 505-536). Sumber legitimasinya adalah prinsip senioritas seperti pada masyarakat Sumbawa (Goethals, 2007: 57-60), pemimpin harus menguasai peraturan-peraturan (hukum adat) seperti pada masyarakat Irian Jaya, Melanesia, dan Papua Nugini (Koentjaraningrat, 1984: 132-133) serta adanya kepemimpinan yang bersifat keturunan (genealogis) seperti aristokrat kesultanan Kutai (Magenda, 2010: 
14-16), dan juga keraton Yogyakarta (Suyanto, 2002). Sedangkan terkait relasi penguasarakyat yang relevan ialah studi Moertono (1985) tentang kawula-gusti pada masyarakat Jawa. Berbagai studi tersebut penting, relevan, dan sejajar dengan studi tentang suku Dayak Ma'anyan sebab sama-sama memandang pentingnya legitimasi kekuasaan dan relasi penguasa rakyat, yang tidak saja relevan dalam kekuasaan tradisional, tetapi relevan dalam kekuasaan modern masa kini dalam masa otonomi daerah dan desentralisasi juga.

Penelitian ini menggunakan metode deskriptif explanatory yakni kombinasi antara penelitian deskriptif dan explanatory. Penelitian deskriptif menjawab pertanyaan "apa", sedangkan eksplanasi menjawab pertanyaan "mengapa" dan "bagaimana". Teknik analisis data secara kualitatif interpretatif, yaitu mengangkat secara ideografis berbagai fenomena dan realitas sosial, teori yang dihasilkan mendapatkan pijakan yang kuat pada realitas, bersifat kontekstual, dan historis (Somantri, 2005: 64). Penelitian dilakukan sejak April 2014 sampai Maret 2017 di daerah suku Dayak Ma'anyan di Kabupaten Barito Timur, khususnya di desa-desa kecamatan Paju Epat. Data yang digunakan ialah data sekunder berupa dokumen-dokumen hasil penelitian yang relevan, sejarah lokal yang mereka tulis maupun tuturkan sebagai data primer melalui wawancara mendalam dengan tokoh-tokoh adat dan menggunakan data lisan seperti Taliwakas (cerita tentang pemimpin), Hiyang Wadian (nyanyian suci imam suku dalam upacara adat), Sorosilah (sejarah asal usul pemimpin) dan hukum adat Dayak Ma'anyan. Penulis juga melakukan observasi lapangan melihat praktik upacara dan keagamaan mereka serta hal-hal lain yang relevan. Interpretasi data menggunakan teori keabsahan atau legitimasi religius Franz Magnis Suseno dan teori hubungan penguasa-rakyat dari Soemarsaid Moertono.

\section{PEMBAHASAN}

Untuk dapat memahami lebih mendalam pemikiran suku Dayak Ma'anyan, perlu diselidiki dan dipahami segala sesuatu yang menyangkut adat dan tradisi mereka, yang sering muncul di dalam mitos (Ukur, 1974: 4). Kendati mitos itu sering disebut tidak masuk dalam logika, terkadang tidak realistis, tetapi justru di dalam mitos itu sering menyimpan fakta tersembunyi (Borneo, 2013: 10). Pada masa lampau pemikiran khusus tentang politik dan negara tidak terdapat secara khusus, tetapi bercampur dengan segala macam sendi kehidupan dari masyarakat, terutama bercampur dengan masalah kepercayaan dan agama (Noer, 1983: 109-110). Dalam konteks tersebut penelitian ini dilakukan untuk melihat bagaimana praktik kekuasaan khususnya mengenai keabsahan atau legitimasi kekuasaan serta hubungan penguasa dengan rakyat dalam kehidupan suku Dayak Ma'anyan di masa lampau.

Pendekatan keabsahan atau legitimasi religius dari Franz Magnis-Suseno dinilai relevan sebagai landasan teori untuk menganalisis data mengenai keabsahan atau legitimasi kekuasaan dalam pemikiran politik suku Dayak Ma'anyan. Dalam konteks kekuasaan religius terdapat tiga unsur yaitu Pertama, penguasa harus menunjukkan diri mampu untuk memegang kekuasaannya; Kedua, seseorang hanyalah betul-betul dianggap berkuasa apabila masyarakat di bawah pemerintahannya berada dalam keadaan adil makmur; dan Ketiga, penguasa menunjukkan mutu mental dan sikap budi yang merupakan prasyarat kemampuannya untuk berhubungan dengan alam gaib, yaitu menjalankan kekuasaan tanpa perlu memakai kekuasaan atau tindakan-tindakan yang kasar (Suseno, 2003: 39-47).

Keabsahan atau legitimasi kekuasaan dalam pemikiran politik suku Dayak Ma'anyan dipandang bersifat religius sebagaimana pandangan Suseno tersebut adalah dapat dilihat dari Pertama, kronik mereka yang menceritakan mitos kehidupan dan penggunaan kekuasaan pada masa kerajaan Nan Sarunai dan sesudahnya memperlihatkan betapa pemimpin mereka di masa lalu menggunakan kekuasaan religius untuk memerintah dan diwariskan hingga kepada para pemimpin mereka di masa kini. Kedua, kekuasaan yang dipraktikkan di 
masa lalu itu menampilkan diri dalam berbagai wujud, tetapi pertama-tama ia merupakan suatu kekuatan, hanya karena ia merupakan kekuatan maka ia dapat menjadi kekuasaan (Kusumohamidjojo, 2014: 137).

Apa yang diwarisi di masa kini mengenai adat, politik termasuk keabsahan atau legitimasi kekuasaan, petugas adat adalah berasal dan berawal mula dari Nan Sarunai. Lambang yang menunjukkan bahwa Nan Sarunai merupakan tempat di mana seluruh hukum adat dan petugas adat tersusun lengkap adalah dengan adanya Balai Datu Jatuh Kabilawan (Gedung Besar Berpintu Seratus). Pasca "Sarunai Usak Jawa" kemudian diwarisi oleh 40 orang Patih (Patis Epat Pulu) dan 7 (tujuh) orang Pangeran (Uria Pitu) yang menyebarkannya ke seluruh tanah Dayak di Kalimantan (Keloso, 1999: 124). Dalam Sorosilah Nan Sarunai dinyatakan kekuasaan di kerajaan Nan Sarunai sebelum dan sesudahnya beserta dan pemimpinnya yang terkenal, yaitu (1) Tumpuk Laliku Meah (sebelum tahun 1305). Berpusat di Hujung Panti, dekat Pangambangan, Kalimantan Selatan. Pemimpinnya adalah Pangulu Nini Punyut; (2) Kerajaan Nan Sarunai (1305-1358). Berpusat di Kayu Tangi, dekat Martapura, Kalimantan Selatan. Pemimpin yang terkenal adalah Raja Anyan; (3) Bangi Sampa Tulen (1358-1389). Berpusat di sebelah utara Kota Tamiang Layang, Barito Timur, Kalimantan Tengah. Pemimpin yang terkenal adalah Uria Napulangit; (4) Tanjung Nagara (1365-1535). Berpusat di Amuntai, Hulu Sungai Utara, Kalimantan Selatan. Pemimpin yang terkenal adalah Uria Gadung; (5) Lasi Muda (1535-1850). Berpusat di Dayu, Barito Timur, Kalimantan Tengah. Pemimpin yang terkenal adalah Uria Biring, dan (6) Landschaap Sihong (1850-1942). Berpusat di Telang, Barito Timur, Kalimantan Tengah. Pemimpin yang terkenal adalah Suta Ono.

Di Tumpuk Laliku Meah untuk pertama kali kehidupan mereka mulai menetap dan teratur dengan dipimpin oleh seorang perempuan bernama Etoh atau yang lebih dikenal dengan gelar Pangulu Nini Punyut. Dalam kepercayaan mereka, Nini Punyut ditunjuk langsung oleh Tuhan untuk me- mimpin masyarakat suku Dayak Ma'anyan agar teratur dan tenteram serta dapat mencapai kehidupan yang makmur. Mereka juga percaya, kepada Nini Punyut diturunkan untuk pertama kali hukum adat Dayak Ma'anyan baik untuk mengatur kehidupan manusia di dunia maupun untuk upacara kematian. Dalam Sorosilah (riwayat Nan Sarunai) dan Taliwakas (cerita tentang kepemimpinan) dinyatakan bahwa Nini Punyut adalah anak dewa penguasa langit bernama Sawalang Gantung dan dewa penguasa bumi bernama Ungkup Batu. Nini Punyut adalah anak pertama, ia diutus pergi ke Nan Sarunai. Di Tumpuk Laliku Meah, sebelum muncul nama Nan Sarunai, kepada Nini Punyut diturunkan aturan adat oleh Tuhan yaitu 9 (sembilan) aturan untuk tata kelola kehidupan dan 7 (tujuh) aturan untuk pelaksanaan upacara kematian. Aturan tersebut diberikan oleh Tuhan kepada Nini Punyut karena ia mampu membuka segumpalan benang kusut yang dilempar Tuhan dari langit. Hanya Nini Punyut yang mampu membukanya, sementara orang lain penduduk desa (Tumpuk) setempat tidak mampu. Setelah dibuka, isi gumpalan benang tersebut adalah sejumlah aturan yang mesti dilaksanakan dan dipimpin oleh orang yang dapat membukanya.

Kini aturan tersebut dikembangkan menjadi 24 jenis aturan untuk mengelola kehidupan dan 19 jenis aturan untuk upacara kematian yang termuat di dalam hukum adat Dayak Ma'anyan. Aturan tersebut masih dilaksanakan hingga kini oleh masyarakat suku Dayak Ma'anyan. Dua aturan di antaranya mengatur tentang kekuasaan dan kepemimpinan yaitu Dudus (pelantikan pemimpin secara adat), dan Kawit Kinte (proses belajar aturan adat dan kepemimpinan). Aturan itu juga mengatur hak pemimpin yaitu (1) Menerima Walasan (hadiah); (2) Melaksanakan Tung'ngu (perintah mengusir atau ekstradisi rakyat keluar dari kampung karena kesalahan yang tidak bisa diampuni); (3) Melaksanakan Pillah (memalas, upacara penyucian kampung); (4) Melaksanakan Sumpah adat (mengucapkan ikrar); (5) Melaksanakan Persaban (berkewajiban melindungi rakyat); dan (6) Berwenang 
menerapkan Mako Baloh Nyiang Pe'e Piak (pelanggaran adat perceraian).

Hak-hak kekuasaan tersebut diperoleh dari dua sumber yaitu Pertama, Tuhan yang menurunkan aturan adat kepada manusia melalui Nini Punyut, dan Kedua, Nanyu yang merupakan roh leluhur atau nenek moyang. Pemimpin memegang peran penting dalam pelaksanaan hukum adat dan pemerintahan secara umum, sementara rakyat mengikutinya. Dalam konteks tersebut Nimer Widen menulis:

"Seseorang yang telah menduduki suatu jabatan tertentu, maka ia akan menduduki jabatan tersebut sampai ia meninggal dunia. Tidakpernah suku Dayak Ma'anyan mencopot seseorang dari jabatannya sewaktu ia masih hidup, ini karena sewaktu pemimpin tersebut diangkat menjadi pemimpin, mereka sudah sangat berhati-hati memilih dan mengangkatnya. Sebab itu, mereka berpandangan bahwa pemimpin tersebut adalah benar-benar seseorang yang dapat diandalkan. Ketika telah dipilih dan diangkat, suku Dayak Ma'anyan mempunyai kepercayaan bahwa pemimpin yang tidak baik akan cepat berlalu. Ada suatu kuasa lain yang akan mengontrol setiap pemimpin, menghukumnya kalau curang atau tidak adil, dan sebaliknya akan melindunginya jika berbuat baik." (Widen, 1996: 128).

Menempatkan sumber kekuasaan berasal dari kepercayaan kepada roh-roh leluhur (Nanyu) dan Tuhan, maka dalam pemikiran politik suku Dayak Ma'anyan, kekuasaan dipahami sebagai realitas adiduniawi, gaib atau ilahi. Sumber kekuasaan dari Nanyu ini antara lain dimiliki Suta Ono selaku kepala suku Dayak Ma'anyan Paju Epat dan kepala pemerintahan Landschaap Sihong (1850-1894). Mallinckrodt menulis.

"Suta Ono adalah kepala suku Dayak Ma'anyan yang begitu termasyur. Pada waktu ia mengadakan perjalanan bersama Kumpeni ke Motallat, pada suatu malam ia tidur dan bertemu dalam mimpinya dengan dua orang perempuan yang memperkenalkan diri sebagai: Nanyu Bukit Nandrueh (Nanyu dari Bukit Kembar). Mereka semalaman tinggal bersama dia, dan mereka menganjurkan kepadanya supaya dalam keadaan-keadaan bahaya meminta pertolongan mereka, dan agar selalu menyediakan sesajen bagi mereka. Suta Ono menjadi berkuasa dan mulia, karena ada sang pelindung yang menjadi keramat keluarga. Suta Ono itu adalah pahlawan orang Ma'anyan yang sangat dicintai dan sampai sekarang sangat dipuja......Menjadi jelas ternyata di sini, bagaimana sang pelindung pribadi, yang hakikatnya seorang leluhur, menjadi sang keramat keluarga, dan bagaimana sang keramat keluarga ini berkat pemujaan pahlawan akhirnya naik tingkat menjadi dewa suku, sementara tugas dewa itu sudah tergambar, yaitu memberi kebahagiaan dan kemakmuran" (Mallinckrodt, 1974: 13).

Suku Dayak Ma'anyan percaya tentang adanya oknum pencipta atau Ilah yang mereka gambarkan sebagai pencipta manusia pertama yang mereka sebut Hiyang Piumung Jaya Pikuluwi (Tuhan Yang Maha Kuasa) sebagai salah satu sumber kekuasaan (Miter, 2015: 13). Penguasa tersebut adalah penguasa alam semesta secara keseluruhan. Akan tetapi, dalam setiap keluarga, menurut Mallinckrodt, keluarga-keluarga suku Dayak Ma'anyan memiliki makhluk pelindung masing-masing, yaitu seperti dinyatakan berikut ini:

\footnotetext{
“Orang Ma'anyan memiliki santo pelindung keluarga yaitu Nanyu, yang pada awalnya adalah nenek moyang mereka, tetapi lama kelamaan ia menjadi semacam makhluk supernatural..... Nenek moyang adalah pelindung pribadi, mereka mengembangkan makhluk suci untuk keluarga masing-masing dan bagaimana hal tersebut nampaknya cara untuk memuja pahlawan sampai dengan Tuhan, dan tugas Tuhan adalah pemberi kebahagiaan dan kesejahteraan" (Mallinckrodt dalam Miter, 2015: 13).
}

Paham kekuasaan seperti demikian oleh Franz Magnis-Suseno disebut legitimasi religius. Dalam legitimasi religius dipahami hakikat kekuasaan bersifat adiduniawi dan adimanusiawi, berasal dari alam gaib atau termasuk Sang Ilahi. Manusia yang berkuasa bukan manusia biasa lagi melainkan ikut termasuk alam duniawi itu. Alam gaib itu maha penting bagi manusia, dan manusia langsung hidup dari dan bersama dengan alam. Alam semesta pun mempunyai segi lahir dan batin. Di belakang alam yang kelihatan terdapat alam gaib yang tidak kelihatan (dalam kepercayaan rakyat dipersonifikasikan dalam pelbagai macam roh yang harus diperhitungkan dalam segala tindak-tanduk manusia). Dalam hal ini kekuasaan politik dibina dengan penguasa alam 
gaib secara lahir dan batin melalui berbagai upacara seperti selamatan, sesajen, doa, dan sebagainya untuk menjalin hubungan baik dengan kekuatan-kekuatan halus itu (Suseno: 2003: 31-33). Kekuasaan dalam pandangan seperti ini bersumber dari kepercayaan dan agama (Budiardjo, 1998: 62).

Secara tradisional bukanlah etis atau tidaknya sebuah kekuasaan, melainkan kekuasaan dipahami sebagai partisipasi dari kekuatan alam gaib atau adikodrati, kekuasaan itu berpartisipasi dalam kemutlakan haknya. Legitimasi religius, yang menyandarkan kekuasaan kepada kekuatan ilahiah dan roh leluhur dalam konsepsi pemikiran politik suku Dayak Ma'anyan paling tidak memuat beberapa unsur penting untuk melihat kemampuan seorang penguasa atau pemimpin menjalankan kekuasaannya, yaitu kepandaiannya, kepintarannya, kemampuannya menjalin relasi dengan penguasa adikodrati, kebijaksanaannya, dan tidak menyimpang dari kaidah-kaidah atau aturan yang berlaku. Prasyarat tersebut melekat dalam legitimasi religius terhadap pemimpin atau penguasa suku Dayak Ma'anyan di masa lalu seperti digambarkan di atas, yaitu Nini Punyut sebagai penerima aturan adat dari Tuhan dan Suta Ono yang memiliki Nanyu sebagai pelindung.

Dalam pemikiran politik suku Dayak Ma'anyan dan ini pernah diimplementasi di masa lalu, kekuasaan yang adikodrati, ilahiah dan religius kerapkali berhubungan dengan hal-hal yang mistik atau supranatural, dan secara umum memerlukan suatu konsep simbol kekuasaan. Konsep simbol kekuasaan tersebut sangat penting sebagai simbol kuasa seorang pemimpin dan sebagai legitimasi penyerahan atau pelimpahan kekuasaan. Pada masyarakat suku Dayak Ma'anyan Paju Epat di desa Balawa dinyatakan ada sebuah Bumbung Wilaruji, yakni sebagai simbol pemegang kekuasaan di kalangan pemimpin suku Dayak Ma'anyan Paju Epat desa Balawa. Wilaruji tersebut dipegang turun-temurun sebagai pengikat garis keturunan dengan leluhur, dan pemegangnya adalah sosok yang memegang kekuasaan adat dan politik formal di desa tersebut. Demikian seterusnya wilaruji sebagai senjata pusaka tersebut berganti tangan atau berpindah tangan kepada pemimpin berikutnya (Wawancara, Syahran A, 2017; Mangkujati, 2003). Simbol tersebut dinyatakan sebagai Pusaka atau Keagungan.

Sementara di kalangan suku Dayak Ma'anyan Paju Epat desa Telang, yang merupakan keturunan kepala suku Suta Ono, dinyatakan bahwa mereka memiliki sebuah pedang, sejenis pedang mandau, sebagai Pusaka atau Keagungan milik Suta Ono yang diturunkan kepada keturunannya di masa kini. Salah satu keturunan Suta Ono yang mewarisi dan memegang pusaka tersebut ialah Gumarawan Pantie yang pernah menjabat Pj. Bupati Barito Timur tahun 2002-2003. Senjata itu adalah simbol pusaka atau keagungan keluarga, bagi yang memegang atau menyimpannya dipercaya kepadanyalah diturunkan anugerah kekuasaan dan kepemimpinan.

Dengan demikian, konsepsi pemikiran politik suku Dayak Ma'anyan mengenai kekuasaan, legitimasinya berkaitan dengan hal-hal yang religius, supranatural, ilahiah, bertumpu pada simbol-simbol kekuasaan (pusaka atau keagungan) yang dianggap sakti dan memiliki nilai kharisma di baliknya. Dalam berbagai konsep tersebut terkandung adanya kewibawaan penguasa, rasa percaya diri, mengandung "pangiwuruh" (kharisma), dan dalam rangka menempatkan kekuasaan seorang penguasa sebagai pusat kekuasaan yang utama, menyeluruh, dan mulia.

Keabsahan dan legitimasi kekuasaan dengan demikian melekat pada diri penguasa tatkala Pertama, penguasa mampu menunjukkan diri sebagai pemimpin yakni ada ketertundukkan rakyat padanya, hal ini digambarkan oleh sosok Nini Punyut yang mampu menerapkan aturan adat yang diturunkan Tuhan untuk mewujudkan kehidupan masyarakat suku Dayak Ma'anyan pada masanya yang tenteram, aman, tertib, dan teratur. Bahkan aturan adat tersebut diwarisi dan tetap diimplementasi di masa kini oleh masyarakat suku Dayak Ma'anyan sebagai hukum adat. Satu di antara aturan adat tersebut yang diimplementasi dalam politik modern masa kini adalah Dudus yaitu pengangkatan 
pemimpin politik seperti bupati dan gubernur secara adat dan pemberian gelar pemimpin suku. Kedua, pemerintahan yang dijalankan dapat membuat rakyat hidup makmur, hal ini digambarkan oleh sosok Raja Anyan selaku raja kerajaan Nan Sarunai di mana ia mampu membawa rakyat hidup makmur. Sorosilah Nan Sarunai menyatakan keadaan Nan Sarunai pada masa kepemimpinan Raja Anyan, sebagai berikut:

"Balai Janyar Suei Waruga Tingkat Walu, Balai Jatuh Kabalawang Riwu Katalaga Rampan Uri Babinangulun Tihang Putaraja, Kawan Amas Bakakiwik, Lehung Gansa Alumingar, Malawen Anak Unru Raja Wata Pea Wulan, Bukah Panangkur Balai Dauh Marak Manta Wulung Sadai Bulan, Agung Devung, Agung Depak, Agung Desai, Agung Garinsingan, Ganning Hannak Lala Hena Tipak Jaring Parei Nimang Kalungap Pinang Muda Palu Andri Tukal Banang, Sisik Anuh Lubar Kapas, lengan ni ngaliere nanang Gunung Pangunraun, ngalikau ngasasifat watu ngampet malem".

(Terdapat Aula Besar Bersambung Sembilan Bertingkat Delapan, Aula Besar tempat Pertemuan Raja, Emas Bertebaran, Lesung terbuat dari emas, banyak piring besar untuk tempat makan Raja sebersih cahaya bulan, Gong Besar, Gong terbuat dari emas, kangkanong alat musik dan menari, gelang emas sebesar kumpalan padi, sebesar biji pinang muda, semuanya berasal dan berada di Gunung Pangunraun).

Oleh karena kemakmuran itu, Nan Sarunai dikenang dan dimitoskan sebagai masa keemasan dan kejayaan kehidupan masyarakat suku Dayak Ma'anyan karena kepemimpinan Raja Anyan di Nan Sarunai dipandang sebagai kekuasaan yang absah dan legitimate dan tetap dikenang hingga masa kini. Ketiga, penguasa menjalankan kekuasaannya dengan kekuatan yang diperoleh dari kekuatan roh nenek moyang (Nanyu), yang dapat memberikannya mutu mental dan sikap budi yang baik, sekaligus sebagai pelindung dan penjaga diri pemimpin dan warga suku. Pemimpin suku Dayak Ma' anyan di masa lalu yang menjalankan kekuasaan dengan menyandarkan kekuatan dan kekuasaannya kepada Nanyu, dan sebab itu ia memiliki keabsahan dan legimimasi secara religius adalah kepala suku Suta Ono ketika menjadi Kepala Landschaap Sihong tahun 1850-1894 di mana seperti dikatakan Mallinckrdot ia dilindungi Nanyu.

Salah satu wujud pemikiran politik terkait kekuasaan seperti dijelaskan tersebut, yang masih diwarisi dan diimplementasi dalam konteks politik modern masa kini oleh masyarakat suku Dayak Ma'anyan ialah Dudus, yaitu pengangkatan atau penobatan pemimpin politik secara adat sekaligus pemberian gelar pemimpin suku. Kepada Teras Narang Gubernur Kalteng dua periode (2005-2015), Zain Alkim Bupati Barito Timur dua periode (2003-2013) dan Ampera A. Y. Mebas Bupati Barito Timur saat ini (2013-2018) masyarakat suku Dayak Ma'anyan melalui organisasi lokal Dusmala dan Dewan Adat Dayak kabupaten melantik dan menobatkan mereka menjadi pemimpin suku dan memberi gelar Dambung Panning Maleh. Tokoh Panning di masa lalu adalah sosok revolusioner pasca "Sarunai Usak Jawa" yang membawa mereka tetap bertahan hidup dan eksis walaupun negeri mereka hancur akibat kalah perang.

Dalam pemikiran mereka, dalam politik modern masa kini hendak diwujudkan pemimpinidealmelaluiperan adatsebagaimana mereka pernah memiliki pemimpin di masa lalu dalam konteks kehidupan suku. Konsep hukum adat Dayak Ma'anyan menyatakan penguasa atau pemimpin ideal adalah (1) berasal dari garis keturunan "kasata amau" atau "tutur amau" (golongan pemimpin); (2) memiliki gelar pemimpin (galar mantir); (3) menjalani proses dudus (dilantik atau dinobatkan melalui upacara adat); dan (4) melalui proses kawit-kinte (belajar peraturan adat dan kepemimpinan). Kalaupun tidak dapat memiliki semua syarat tersebut, seorang pemimpin ideal paling tidak memiliki salah satu saja. Syarat tersebut menggambarkan keberadaan pemimpin di kalangan suku Dayak Ma' anyan adalah absolut, hanya orang tertentu yang dapat menjadi pemimpin. Sebaliknya walaupun seseorang adalah keturunan pemimpin, tetapi tidak memegang suatu jabatan politik dalam masyarakat, ia tidak dapat menjalani proses Dudus. 
Dalam pemikiran politik suku Dayak Ma'anyan, pola hubungan penguasa dengan rakyat digambarkan dalam dua hubungan yaitu "putak amau" (golongan pemimpin) dengan "putak ime" (golongan rakyat) dan sebagiannya adalah "putak walah" (golongan budak), atau secara spesifik disebutkan relasi tutur mantir-ulun rama. Pola hubungan ini muncul paska "Sarunai Usak Jawa" pada abad 14 yaitu sebagai pengaruh Hindu yang dibawa oleh Majapahit. Sementara dalam budaya politik Jawa, pola hubungan penguasa dengan rakyat tergambarkan dalam konsep kawula-gusti, yang memiliki ciri (1) dalam banyak aturan ada garis pemisah yang resmi dari hierarki sosial yang ada seperti tata cara pemakaian busana, penggunaan bahasa (kramainggil, krama, madya, dan ngoko), penggunaan warna atau cara penghormatan; (2) adanya pemikiran tentang nasib, takdir, yang dinyatakan dalam kata pinesti (ditentukan) dan tinitah (ditakdirkan); (3) terdapat dua lapisan utama masyarakat yaitu wong cilik (orang biasa) dan penggede (golongan penguasa); (4) perolehan kekuatan tambahan melalui semadi dan laku tapa; (5) tidak hanya menunjukkan hubungan antara yang tinggi dengan yang rendah, tetapi lebih menunjukkan saling ketergantungan yang erat antara dua unsur yang berbeda, tetapi tak terpisahkan, dua unsur ini merupakan dua aspek dari hal yang sama, penyatuan ini dilambangkan dalam wujud keris yang merupakan senjata kebesaran di mana baik sarung maupun mata keris diberikan penafsiran yang sangat mistik; dan (6) sumber informasi penting tentang hubungan kawulagusti adalah wayang (Moertono, 1985: 18-19).

Kalau pada masyarakat Jawa hubungan antara raja dan rakyat diketahui melalui informasi cerita wayang, maka pada masyarakat suku Dayak Ma'anyan diketahui melalui cerita tentang kepemimpinan dalam Taliwakas dan hukum adat Dayak Ma'anyan yang muncul dalam upacara-upacara adat. Hal ini terkonfirmasi seperti pandangan Liddle yang mengatakan "kehidupan suku Dayak yang sejati adalah kehidupan yang tersembunyi, yang tidak diungkapkan kepada orang lain, dan hanya dapat diketahui melalui upacara dan cerita mereka" (Liddle, 1997: 300). Dalam cerita tersebut antara lain diketahui pola hubungan penguasa-rakyat tidak hanya menggambarkan antara pihak penguasa dengan pihak yang dikuasai, atau hubungan antara pihak yang tinggi dengan yang rendah, tetapi memperlihatkan saling ketergantungan antara kedua pihak. Ketergantungan itu dinyatakan dalam konsep sumpah adat pelantikan pemimpin(Dudus), yaitu seperti berikut:

\begin{abstract}
"Hang hadapan Tuhan Nguasa Alatala Ngaburiat Hiyang Piumung Jaya Pakuluwi, Tuah Hukat Tala Mana hang hadapan kawan pajabat Hi... (nama pemimpin yang disumpah) andri tugas jari .... (nama jabatannya), bila hanye puang babujur menunaikan tugas ni jari ...... (nama jabatannya) puang satia, puang jujur, puang witu, atawa ipusu, atawa nipu, ngakal, isa marugikan ulun rama, maka pamelumni yalah habu galis samiding, ang uweng arati lenuh yalah rangi".
\end{abstract}

(Di depan Tuhan Yang Maha Kuasa, Sumber Kuasa dari negeri asal mula manusia, yang berkuasa atas segala makhluk hidup, di depan semua pejabat .... (nama pemimpin yang disumpah) dengan tugas jabatan sebagai .... (nama jabatannya), kalau dia tidak betul-betul menjalankan tugas dan jabatannya sebagai ....... (nama jabatannya), tidak setia, tidak jujur, tidak lurus, atau berbohong, atau menipu, menyeleweng atau apapun yang bersifat merugikan rakyat, maka kehidupannya seperti debu yang sirna terbang, dan hidupnya tidak ada artinya hancur seperti garam). (Wada, 2003: 26-28).

Konsep tersebut menyatakan bahwa ulun rama (rakyat) sebagai objek kekuasaan merupakan tujuan dan sasaran seorang pemimpin menjalankan kekuasaan. Penguasa harus menggunakan kekuasaannya untuk sepenuhnya melayani rakyat, bukan untuk kepentingan pribadi. Kedudukan pemimpin dalam pemikiran politik suku Dayak Ma'anyan dengan demikian sama seperti kedudukan raja di Jawa, ditempatkan pada tampuk tata masyarakat, dan jauh di atas jangkauan orang biasa. Pada masa Kerajaan Mataram II di Jawa terdapat ikhtiar pemikiran tentang hubungan raja dengan kawulanya tergolong ke dalam tiga konsep (1) Hubungan pribadi yang akrab 
yang disertai oleh perasaan saling mengasihi dan menghormati dianggap sebagai pola atau model baku dalam komunikasi sosial; (2) Takdir menetapkan keunggulan manusia dalam masyarakat apakah dilahirkan sebagai abdi atau tuan. Akibatnya bahwa manusia tidak punya pilihan lain kecuali melakukan kewajibannya seperti telah ditentukan oleh takdir; dan (3) Penguasa (dan para pejabatnya) dari segi kebijaksanaan pemerintahan praktis, harus memperhatikan para warganya seperti seorang tua mengasuh anak-anaknya, dengan demikian sang penguasa memiliki sikap keunggulan (superioritas) yang melindungi, sedangkan yang diperintah memiliki sikap pengabdian yang tulus (Moertono, 1985: 43).

Ikhtiar tersebut relevan dan sejajar dengan pemikiran politik suku Dayak Ma'anyan, yaitu seperti diungkapkan dalam Taliwakas dan hukum adat sebagai berikut: Pertama, ada ketergantungan rakyat kepada pemimpin jika terjadi suatu masalah dalam kehidupan rakyat, sehingga pemimpin harus turun tangan menyelesaikan masalah tersebut. Dalam artian, takdir selaku rakyat tidak dapat menyelesaikan masalahnya sendiri sehingga harus pergi kepada pemimpin untuk menyelesaikannya seperti ada sengketa harta warisan keluarga serta perselisihan antar keluarga atau sesama warga suku; Kedua, ada ketergantungan rakyat kepada pemimpin jika terjadi krisis kepemimpinan, yaitu jika dalam suatu masa terjadi ketiadaan pemimpin dari kelas pemimpin, maka hukum adat mengatur kelas rakyat dapat diangkat menjadi pemimpin melalui suatu upacara adat khusus yang disebut "nindrik langka", tetapi upacara ini tetap tidak dapat mengangkat status kelas rakyat menjadi kelas pemimpin, pemimpin tersebut tetap berstatus kelas rakyat, sampai pada masanya hadir pemimpin yang berasal dari kelas pemimpin. Hal ini menandakan ada keterpisahan antara pihak penguasa dengan pihak yang dikuasai, ada jarak di antara keduanya, dan memperlihatkan keunggulan (superioritas) golongan pemimpin terhadap golongan rakyat. Ketiga, hubungan pribadi yang akrab antara rakyat dengan pemimpin tergambarkan di dalam berbagai upacara adat, di mana misalnya sebuah upacara tidak dapat dilaksanakan bila tanpa kehadiran pemimpin (Mantir) untuk memimpin upacara, lalu dominasi berbicara sampai mengambil keputusan penting upacara juga dilakukan oleh pemimpin. Sedangkan rakyat, meskipun banyak hadir dalam upacara dan ikut duduk di balai adat, sebagian besar tidak berbicara, hanya mendengar dan menyaksikan pembicaraan pemimpin hingga melaksanakan keputusan upacara yang diputuskan pemimpin. Hal ini menggambarkan sebagai cara menghormati dan menghargai kedudukan pemimpin serta model baku komunikasi antara rakyat dengan pemimpin.

Dalam tradisi Jawa terdapat garis pemisah resmi yang tegas dari hierarki sosial antara penguasa dan rakyat melalui tata cara pemakaian busana, penggunaan bahasa, penggunaan warna atau tata cara penghormatan, sementara dalam konsepsi pemikiran politik suku Dayak Ma'anyan sekarang garis pembeda itu tidak ada. Pemakaian busana, bahasa dan tutur kata, cara penghormatan, tempat duduk dalam upacara adat, dan lain-lain sudah bercampur baur di antara dua kelas tersebut. Ini karena strata sosial atau kelas sosial di dalam pemikiran politik suku Dayak sudah dihapus di era masuknya program misi agama Kristen dan kolonial Belanda. Penghapusan ini terjadi dalam program penebusan budak (Pandeling) oleh pendeta-pendeta Kristen terhadap kalangan rakyat yang dijadikan budak atau pelayan pada masa kehidupan masyarakat suku. Selain itu, sistem strata kelas juga secara umum dihapus dalam perjanjian damai antara para kepala suku Dayak di Tumbang Anoi tahun 1894 (Usop, 1994). Kepala Suku Dayak Ma'anyan yang hadir dalam perjanjian damai tersebut adalah Suta Negara (kepala Landschaap Sihong 1894-1920). Sejak saat itu, pola relasi sosial masyarakat suku Dayak secara umum dan juga suku Dayak Ma'anyan berangsur-angsur semakin egaliter hingga masa kini.

Akan tetapi, dalam beberapa kasus garis pembeda tersebut masih tampak terlihat sampai beberapa waktu terakhir, Pertama, masyarakat kelas putak walah (budak) yang merupakan 
bagian dari kelas rakyat (putak ime) memiliki tugas khusus saat pelaksanaan upacara adat kematian Ijambe pada masyarakat suku Dayak Ma'anyan Paju Epat, di mana mereka menjadi "panyigi ramai" (penjaga api obor), alat penerang upacara yang dipasang sepanjang jalan dari balai adat ke lapangan tempat pelaksanaan upacara (Ukur, 1974: 19). Aturan ini berlangsung sampai sekitar tahun 1960an karena sejak saat itu aturan ini dihapus untuk alasan kemanusiaan dan persamaan hak dalam masyarakat (Wawancara, Syahran A, 25 Maret 2017). Kedua, kelas "walah" tidak mempunyai tambak (rumah suci tempat penyimpanan tulang orang yang meninggal dunia). Saat meninggal dunia, setelah dilaksanakan upacara adat kematian Ijambe, tulang mereka dimasukkan ke dalam kosi (guci terbuat dari tanah liat). Upacara kematian ini adalah upacara kematian terakhir dan tertinggi dalam tradisi suku Dayak Ma'anyan untuk menghantar arwah atau roh nenek moyang pergi ke surga beserta segenap harta kekayaannya. Sampai masa kini tradisi ini masih dipertahankan dan masih ada pembedaan antara kelas pemimpin yang mempunyai tambak sendiri dengan kelas rakyat yang tidak mempunyai tambak. Ketiga, pada masa pemerintahan kolonial Belanda keluarga kelas pemimpin diberi kepercayaan menduduki jabatan strategis dalam pemerintahan yaitu kepala distrik (bupati) dan kepala onderdistrik (camat), sementara rakyat yang bukan kelas pemimpin tidak bisa memegang jabatan ini. Di daerah suku Dayak Ma'anyan di Kabupaten Barito Timur dikenal tokoh-tokoh pemimpin dari kelas elite tradisional yang menduduki jabatan penting pemerintahan kolonial yaitu Suta Ono sebagai Kepala Landschaap Sihong (1850-1894), Suta Negara (1894-1920), Raden Badowo (1920-1942), dan Tamanggung Jaya (Djelan) sebagai Kepala Distrik Patai (18571875).

Dalam konteks hak rakyat dalam proses kekuasaan adalah dimanifestasi dalam hak protes rakyat kepada pemimpin atau penguasa. Rakyat juga dapat mengajukan pandangan kritis kepada pemimpin dan dapat menentukan pemimpin mereka secara langsung. Kalau pemimpin dianggap sudah terlalu tua, sakit- sakitan, tidak cakap dalam memimpin dan tidak lagi mampu secara fisik, maka rakyat melalui kepala desa memilih pemimpin baru. Hal ini digambarkan saat penggantian Kepala Suku Dayak Ma'anyan Kampung Sapuluh di Patai tahun 1857. C. Bangert menulis:

\begin{abstract}
"Saya ditunjuk untuk pertama kalinya menjadi saksi terpilihnya seorang laki-laki yang berasal dari kampung kiri distrik Patai untuk menjadi kepala kampong/suku Tamiang Laijang dan diberi gelar Tomonggong Djaija. Semua kepala desa distrik Patai hadir dalam pemilihan tersebut. Tanggal 21 Mei 1857 kepala suku yang baru diangkat dengan sumpah dan ketaatan dengan cara Daijak ke tangan saya. Dia berdiri di tempat terbuka, di dalam lingkaran penonton, semua kepala desa distrik Patai duduk tempat barisan pertama. Kemudian mereka mengacungkan Mandau (pedang Daijak) ke cakrawala, ia memohon kepada Dewa dan Hantu bersaksi bahwa ia akan taat kepada pemerintah dan keadilan untuk rakyatnya akan diberikan. Kemudian dia berjongkok. Selanjutnya Mandou diletakkan di atas kepalanya, dan dia menyatakan siap mati untuk keadilan, selanjutnya dia berdiri. Kemudian datang kepadanya semua kepala desa dan menyentuh dada dan tangan dengan lehernya, kemudian menyerahkan ayam yang baru dibunuh, yang ada di tangan mereka masing-masing. Hal ini dijelaskan kepada saya untuk menjadi tanda bahwa para kepala desa tunduk kepada perintahnya. Akhirnya beberapa wanita tua, mendekati Tomonggong yang baru serta menaburinya dengan beras kuning. Dengan ini upacara selesai." (Bangert, 1860: 161-163).
\end{abstract}

Para kepala suku semacam ini umumnya diangkat menjadi raja oleh komunitas dan anggota sukunya, seperti pada suku Dayak lain di Kalimantan (King, 2013: 325-343). Di kalangan suku Dayak Ma'anyan Paju Epat di masa kini, kepala adat juga dapat diganti atas usulan masyarakat kendati belum sampai selesai masa tugasnya karena alasan kesehatan, usia, dan faktor lain yang tidak memungkinkan menyelesaikan tugasnya. Akan tetapi, bila masyarakat masih menghendaki, maka kendati masa tugasnya sudah selesai kedudukannya dapat diperpanjang sesuai kepentingan tugasnya (Wawancara, Bhaterius, 2017). Demikian juga bila kebijakan-kebijakan yang diambil kepala adat atau pemimpin politik dinilai merugikan rakyat, tidak berpihak 
pada kepentingan rakyat, kebijakannya menyusahkan, hingga secara adat kebijakan itu dinilai melanggar ketentuan adat, maka warga atau rakyat bisa memprotesnya (Wawancara, Dalios, 2017).

Budaya politik suku Dayak Ma'anyan mengenal konsep Paut sebagai wujud hak rakyat dalam kekuasaan dan hingga kini masih relevan diimplementasi dalam politik modern. Paut merupakan hak tidak menegur atau tidak mau berbicara dengan pemimpin bahkan tidak mau bertemu pemimpin. Hal ini dapat dilakukan rakyat karena pemimpin dinilai merugikan rakyat dan tidak ada niat dari pemimpin untuk memperbaiki kesalahannya. Di masa kini di Kabupaten Barito Timur, ada di antara warga suku Dayak Ma'anyan yang mempraktikkan budaya politik paut, dengan tidak mau berbicara atau menegur bahkan untuk bertemu dengan bupati, yaitu karena dinilai ada kebijakan bupati yang tidak sesuai dengan janji-janji politiknya.

Dalam tradisi Jawa, terdapat dua cara untuk menyampaikan suatu pandangan kritis kepada pemimpin yaitu kepada Raja. Pertama, Raja meminta nasihat dari para pegawai tinggi kerajaan, dan Kedua, rakyat berjemur merebahkan diri di alun-alun di depan kraton, dijemur oleh matahari, dan guyuran air hujan untuk memohon perhatian raja atas penderitaan atau ketidakadilan yang mereka derita. Kedua cara tersebut hanya sebatas himbauan dan tergantung keinsyafan Raja sendiri mau menurutinya atau tidak (Suseno, 2003: 46). Terlepas dari cara pelaksanaannya dan bagaimana kemudian tindakan pemerintah atau raja terhadap tuntutan aspirasi itu, paling tidak secara tradisional cara tersebut sebagai wujud pandangan mereka akan hak-hak yang dimiliki rakyat untuk menyampaikan tuntutan dan apirasinya terhadap pelaksanaan kekuasaan.

Dalam tradisi suku Dayak Ma'anyan, budaya politik paut merupakan sebuah gerakan baik secara individu maupun kelompok untuk menuntut hak selaku rakyat karena merasa dirugikan oleh kebijakan pemimpin. Selain paut, di masa kini mereka juga mendirikan organisasi adat yaitu Dewan Adat Dayak untuk menjadi lembaga perwakilan mereka secara tradisional menyuarakan berbagai kepentingan mereka kepada pemimpin politik. di Kabupaten Barito Timur, Damang Kepala Adat senior diposisikan sebagai penasehat bupati dalam struktur Dewan Adat Dayak. Sehingga lembaga adat ini menjadi semacam lembaga perwakilan tradisional warga suku, sekaligus sebagai wadah bagi bupati menerima nasihat dan pandangan kepada tokoh-tokoh adat saat akan mengambil suatu kebijakan politik agar tidak keliru.

Berbeda dengan tradisi masyarakat Jawa yang memperlihatkan tuntutan haknya hanya berupa "himbauan" kepada pemerintah atau raja dengan berjemur di tengah lapangan. Di kalangan suku Dayak Ma'anyan, tuntutan hak mereka tidak sekadar himbauan, tetapi meminta pemimpin atau penguasa "menyelesaikannya" sampai tuntas antara pemimpin dengan rakyat dengan demikian menjalin relasi saling ketergantungan. Hubungan penguasa dengan rakyat dalam pemikiran politik suku Dayak Ma'anyan tidak sekadar hubungan antara pimpinan dan bawahan, atau penguasa dengan pihak yang dikuasai, melainkan ada hubungan ketergantungan, hubungan saling memerlukan dan hubungan yang dekat sebagaimana hubungan anak dan orang tua. Hubungan tersebut dimanifestasi dalam berbagai wujud yang sudah ada dalam tradisi sejak lama, diatur di dalam adat, dan di masa kini masih digunakan kendati dalam beberapa kasus saja.

\section{SIMPULAN}

Pertama, keabsahan atau legitimasi kekuasaan dalam pemikiran politik suku Dayak Ma'anyan terkait dengan hal-hal religius, ilahiah, dan bertumpu pada simbol kekuasaan (pusaka atau keagungan). Di balik faktor tersebut terkandung adanya kewibawaan penguasa, percaya diri, "pangiwuruh" (kharisma), dan dalam rangka menempatkan kekuasaan seorang penguasa sebagai pusat kekuasaan yang utama, menyeluruh, dan mulia. Legitimasi tersebut oleh Franz Magnis Suseno disebut legitimasi religius. Dalam konsepsi suku Dayak Ma'anyan juga terdapat pemimpin ideal yaitu (1) berasal dari garis keturunan 
"kasata amau" atau "tutur amau" (golongan pemimpin); (2) memiliki gelar pemimpin (galar mantir); (3) menjalani proses dudus (dilantik atau dinobatkan melalui upacara adat); dan (4) melalui proses kawit-kinte (belajar peraturan adat dan kepemimpinan). Pemimpin ideal dan memiliki legitimasi secara adat maupun politik dalam kekuasaan adalah yang memenuhi unsur-unsur atau paling tidak salah satu dari unsur tersebut. Di masa kini, pemikiran tersebut mereka implementasi dalam politik modern dengan mengangkat atau menobatkan bupati dan gubernur menjadi pemimpin suku dan memberi gelar pemimpin suku yaitu melalui proses dudus.

Kedua, hubungan penguasa dengan rakyat dalam pemikiran politik suku Dayak Ma'anyan dikonsepsi dalam dua lapis struktur kekuasaan yaitu putak amau-putak ime, atau secara spesifik di dalam hukum adat Ma'anyan disebut istilah tutur mantir-ulun rama. Putak amau atau tutur mantir adalah kelompok elite yang memerintah secara politik maupun adat dalam kehidupan suku, sedangkan putak ime atau ulun rama adalah kelompok rakyat sebagai pihak yang diperintah atau dikuasai. Memang sekarang, hubungan tersebut sudah semakin hilang karena sudah dihapus oleh misi zending Kristen dan pemerintah kolonial Belanda dan masyarakat suku Dayak sudah semakin egaliter. Akan tetapi, dalam beberapa kasus garis pembeda keduanya masih nampak terlihat dalam upacara kematian Ijambe di mana kelas rakyat tidak mempunyai "tambak" (rumah suci pemyimpanan tulang) sendiri. Sedangkan kelas pemimpin dan keluarganya mempunyai "tambak" tersendiri. Saling ketergantungan pemimpin-rakyat dikonsepsikan bahwa rakyat sebagai tujuan implementasi kekuasaan. Sebaliknya pemimpin harus memberi kesejahteraan kepada rakyat, berlaku adil, dan menjunjung hak rakyat secara mulia dan bijaksana. Ada hak-hak pemimpin di dalamnya, dan ada pula hak-hak rakyat yang diekspresikan melalui budaya politik Paut.

Ketiga, suku Dayak Ma'anyan adalah kelompok masyarakat suku di Indonesia yang memiliki ikatan kultural dan identitas etnik sangat kuat, yang mempengaruhi tingkah laku sehari-hari termasuk tingkah laku politik. Kuatnya identitas etnik dalam politik juga terjadi pada suku bangsa Skotlandia dan Wales di Inggris. Menurut Hechter (1979), mereka menuntut perubahan dalam pengelolaan kehidupan politik yaitu pemisahan diri dari negara induk UK (United Kingdom) yang diakibatkan berubahnya pandangan mereka terhadap daerah dan negara induknya. Kebijakan yang diambil negara adalah memberi kebebasan dalam ekspresi seni budaya sebagai identitas kebangsaan dan dapat membentuk pemerintahan daerah yang memiliki kewenangan tertentu. Sementara pada masyarakat suku Dayak Ma' anyan, mereka tidak menuntut pemisahan diri dari pemerintah pusat (Jakarta), melainkan menuntut memberi kebebasan mengelola daerahnya sesuai adat mereka, dan mereka mengangkat elite lokal menjadi patron yang dapat memperjuangkan kepentingan mereka secara lebih luas terutama di tingkat nasional.

Secara praktis, hasil penelitian ini patut dipertimbangkan untuk diimplementasi dalam politik Indonesia masa depan di pusat maupun di daerah. Pertama, syarat pemimpin politik haruslah menguasai aturan yang berlaku dalam masyarakat (sarjana hukum), melalui proses pembelajaran bidang kepemimpinan dan kekuasaan (sarjana ilmu politik atau ilmu pemerintahan), adanya prinsip senioritas (tidak terlalu muda dan juga tidak terlalu tua, ada pembatasan usia), dapat menciptakan kekayaan (kemakmuran) bagi rakyat, dan tidak mempersoalkan kedudukan laki-laki dengan perempuan (gender). Kedua, ada hak rakyat dalam kekuasaan sebagai mekanisme kontrol terhadap pemimpin melalui lembaga perwakilan (dewan adat), rakyat dapat menuntut pemimpin mundur dari jabatannya bila tidak mampu atau tercela (korupsi, menyimpang dari norma), berhak tidak mau bertemu pemimpin (budaya paut) bila pemimpin berlaku tidak adil, dan berhak tidak memilihnya lagi bila kepemimpinannya gagal menciptakan kemakmuran bagi rakyat.

\section{HASIL WAWANCARA:}

Bhaterius. 2017. Wawancara. 
Dalios. 2017. Wawancara.

Dandan, K. A. 2017. Wawancara.

Ngepek, A. 2014. Wawancara.

Suban, K. 2017. Wawancara.

Syahran. 2017. Wawancara.

Udir, R. 2017. Wawancara.

Usop, KMA. M. 2014. Wawancara.

\section{DAFTAR PUSTAKA}

Agun, A, dkk. 2016. Kiaen Wadian Hintek Ijambe (Perjalanan Wadian Saat Upacara Ijambe). Siong: Naskah tidak diterbitkan.

Alkim, Z. 2004. Meniti Buih dari Magantis ke Tamiang Layang. Tamiang Layang: Pemda Barito Timur.

Bae, S. U., G. B. Djanang, dan Martinus. 1995. "Sejarah Suku Dayak Ma'anyan, Banjar dan Merina di Madagaskar". Hasil Penelitian. Jakarta: Museum Nasional RI. Naskah tidak diterbitkan.

Banggert, C. 1860. Verslag Der Reis In De Binnenwaarts Gelegene Streken Van Doessoen Ilir. (Indische Taal Land Volkenkunde IX), hal. 161-163.

Borneo Institut. 2013. "Hapakat Manggatang Utus, Dari Kalimantan Tengah Mencari Identitas". Palangka Raya: Borneo Institut.

Budiardjo, M. 1998. Dasar-Dasar Ilmu Politik. Jakarta: PT. Gramedia.

Gentong, D. dan S. Dusau. 2004. "Hukum Adat Dayak Ma'anyan". Buntok: Pemerintah Kabupaten Barito Selatan. Naskah tidak diterbitkan.

Goethals, P. R. 2007. "Rarak: A Swidden Village of West Sumbawa", dalam Koentjaraningrat (Ed.)., Villages in Indonesia. Jakarta-Kuala Lumpur: Equinox Publishing.

Hechter, M. dan L. Margaret. 1979. “The Comparative Analysis of Ethnoregional Movements". Ethnic and Racial Studies. 2 (3).

Keloso. 1999. “Kemungkinan-Kemungkinan Kristologi Dalam Konteks Budaya
Agama Hindu Kaharingan". Tesis, Jakarta: Sekolah Tinggi Teologi Jakarta.

King, V. T. 2013. Kalimantan Tempoe Doeloe. Depok: Komunitas Bambu.

Klinken, Gerry van. 2010. “Kembalinya Para Sultan: Pentas Gerakan Komunitarian Dalam Politik Lokal", dalam Jamie S. Davidson dkk. (Peny.). Adat Dalam Politik Indonesia. Jakarta: Buku Obor dan KITLV-Jakarta.

Koentjaraningrat. 1984. “Kepemimpinan dan Kekuasaan: Tradisional, Masa Kini, Resmi dan Tak Resmi", dalam Miriam Budiardjo (Peny.). Aneka Pemikiran Tentang Kuasa dan Wibawa. Jakarta: Penerbit Sinar Harapan.

Kusumohamidjojo, B. 2014. Filsafat Politik dan Kotak Pandora Abad 21. Yogyakarta: Jalasutra.

Liddle, R. W. 1997. Islam, Politik dan Modernisasi. Jakarta: Pustaka Sinar Harapan.

Magenda, B. D. 2010. East Kalimantan, The Decline of a Commercial Aristocracy. Singapore: Equinox Publishing.

Magnis-Suseno, F. 2003. Etika Politik: PrinsipPrinsip Moral Dasar Kenegaraan Modern. Jakarta: PT. Gramedia.

Mallinckrodt, J. 1974. Gerakan Nyuli Di Kalangan Suku Dayak Lawangan. Jakarta: Penerbit Bhratara.

Mangkujati, A. 2003. “Wadian Perempuan: Mencari Identitas Dayak Ma'anyan (Masa Kini)", dalam Budi Susanto, SJ (Ed.). Politik dan Postkolonialitas di Indonesia. Yogyakarta: Kanisius.

Mattulada. 1985. Latoa, Satu Lukisan Analisis Terhadap Antropologi Politik Orang Bugis. Yogyakarta: Gadjah Mada University Press.

Miter, H. S. 2015. Amirue dan Roh Kudus: Sejarah Perjumpaan Ulun Ma'anyan dengan Kekristenan. Sendawar, Kutai Barat: YRSKLR dan Araska Publisher. 
Moertono, S. 1985. Negara dan Usaha BinaNegara di Jawa Masa Lampau: Studi Tentang Masa Mataram II, Abad XVI sampai XIX. Jakarta: Yayasan Obor Indonesia.

Nordholt, H. S. 2007. “Bali: Sebuah Benteng Terbuka", dalam Henk Schulte Nordholt dan Gerry van Klinken (Ed.). Politik Lokal di Indonesia. Jakarta: KITLV-Jakarta dan Yayasan Obor.

Noer, D. 1983. Pengantar ke Pemikiran Politik. Jakarta: CV. Rajawali.

Pasande, D. 2011. "Politik Nasional dan Penguasa Lokal di Tana Toraja", dalam dalam Sita van Bemmelen dan Remco Raben (Peny.). Antara Daerah dan Negara, Indonesia Tahun 1950an. Jakarta: Yayasan Obor dan KITLV-Jakarta.

Pilakoanu, R. T. 2010. “Agama Sebagai Identitas Sosial: Studi Sosiologi Agama Terhadap Komunitas Ma'anyan". Disertasi, Salatiga: Kajian Sosiologi Agama, Program Pascasarjana Sosiologi Agama Universitas Kristen Satya Wacana,

Somantri, G. R. 2005. "Memahami Metode Kualitatif". Jurnal Sosial Humaniora "Makara".9 (2): 64.

Sorosilah Nan Sarunai (riwayat kerajaan Nan Sarunai). Naskah tidak diterbitkan. Tanpa tahun.

Suyanto, I. 2002. "Faham Kekuasaan Jawa: Pandangan Elit Kraton Surakarta dan Yogyakarta". Disertasi, Depok: Bidang Studi Ilmu Politik, Program Pascasarjana, FISIP, Universitas Indonesia.
Taliwakas Ma'anyan (cerita tentang kepemimpinan suku Ma'anyan). Tanpa tahun. Naskah tidak diterbitkan.

Ukur, F. 1974. “Ijambe, Upacara Pembakaran Tulang di Kalangan Suku Dayak Ma'anyan di Kalimantan Tengah", Majalah Paninjau, Lembaga Penelitian dan Studi Dewan Gereja-gereja di Indonesia (DGI), Tahun I Nomor 1, 1974, hal. 3-46.

Usop, KMA. M. dkk. 1978. “Sejarah Daerah Kalimantan Tengah: Proyek Penelitian dan Pencatatan Kebudayaan Daerah". Hasil Penelitian, Palangka Raya: Departemen Pendidikan dan Kebudayaan Republik Indonesia dan Dinas Pendidikan dan Kebudayaan Provinsi Kalimantan Tengah.

Usop. KMA. M. 1994. Rapat Damai Tumbang Anoi 1894. Palangka Raya: Setdaprov Kalteng.

Waren, C. 2010. "Adat dalam Praktik dan Wacana Orang Bali: Memposisikan Prinsip Kewargaan dan Kesejahteraan Bersama (Commonweal)", dalam Jamie S. Davidson, David Hanley, Sandra Moniaga (Pany.)., Adat Dalam Politik Indonesia. Jakarta: KITLV-Jakarta dan Yayasan Obor.

Wada, M. 2003 "Adat, Hukum Adat dan Budaya Dayak Ma'anyan Paju Sapuluh". Tamiang Layang, Naskah tidak diterbitkan.

Widen, N . 1995. “Orang Ma'anyan: Dipersatukan oleh Darah", dalam Darius Dubut, dkk (Peny.). Kurban yang Berbau Harum. Jakarta: Balitbang PGI dan Majelis Sinode GKE. 